\title{
Response of reinforced concrete structure subjected to blast loads without and with steel fibers
}

\author{
Raghunandan Kumar R ${ }^{1}$, G.R Reddy ${ }^{2}$, Sunny Dev K ${ }^{3}$, Georgy Job ${ }^{4}$, Alina Benny ${ }^{5}$
}

\begin{abstract}
Analysis of Reinforced Concrete Structures subjected to blast loads in the commercial domain has gained importance due the frequency in which such buildings and structures are being targeted by the terrorists which not only causes serious damage to the structures but also has resulted in loss of precious human life. Though the potential targets and the damages it causes to the structures may be difficult to predict, it is important to consider the blast load in addition to the conventional loads considered in the analysis and design of buildings to minimize the damage caused either due to manmade or accidental blasts. A study is undertaken to compare the effect of inclusion of steel fibers of varying percentages, when subjected to blast loads at different standoff distances of $3 \mathrm{~m}, 6 \mathrm{~m}$ and $9 \mathrm{~m}$ by varying the charge weights when compared to the reinforced concrete with M25 grade at the same standoff distances and charge weights. The variations of the high strains and the lateral deflections are studied when compared to the normal M25 grade concrete with conventional loads. In this research, the analysis of Ground +3 storey reinforced concrete skeletal structure is considered for the analysis. Using PTC CREO 3.0 the 3D modelling of structure and structural elements were generated. HYPERMESH was used for the discretization (meshing) of structure and its elements. Static analysis and blast load analysis was carried out using ANSYS. The blast load parameters such as equivalent overpressure, reflected pressure and time duration based on typical blast wave phenomena was examined.
\end{abstract}

Keywords - Steel Fibers, Blast load, RC Structure, TNT, Standoff distance and High strains.

Raghunandan Kumar $R^{1}$, Sunny Dev $K^{3}$ and Georgy Job ${ }^{4}$, Alina Benny ${ }^{5}$ Christ University, Faculty of Engineering, Bengaluru, India.

G.R. Reddy ${ }^{2}$

Baba Atomic Research Centre, Mumbai, India.

\section{Introduction}

In the past decade, there are several instances where the public and commercial buildings have been targeted by the terrorists with bombs that cause damage to the structures and also resulting in loss of human life, Jun Li, Hao et al and T.Ngo et al (6), (10). Structural loads are an important consideration in the analysis and design of buildings in India. Building codes and Indian standard recommendations require that structures be designed and built to safely resist all actions that are likely to face during their service life, while remaining fit for use. Minimum loads or actions are specified in these building codes for types of structures, geographic locations, usage and materials of construction. Generally, the buildings are analyzed and designed with the static loading conditions along with the safety factors. Dynamic loads result in different response of the structure compared to the static loads. Disasters such as the terrorist bombings on the U.S embassy in Nairobi, Kenya, Dares Salaam, Tanzania in 1998, the Khobar Towers military barracks in Dhahran, Saudi Arabia in 1996, the Murrah Federal Building in Oklahoma City in 1995, and the World Trade Center in New York in 1993 as reported in the literature (10) has shown the need for a thorough examination on the behavior of the structure subjected to blast loads. The study of reinforced concrete structures subjected to blast loads have gained importance, as conventionally the RC structures are not analyzed and designed for blast loads, due to the fact that quantifying the magnitude of the blast load is difficult. The blasting of explosives cause near catastrophic damages on the structure, causing damage to the structural frames both internal as well as external. On the other hand, it also causes loss of life due to the collapse of the structure, chipping of the cladding or spalling of concrete, drifts of the floor and the secondary effects due the damage to the facade and the glazing. There are few software tools available commercially like ANSYS, ABAQUS, ADINA, and NASTRAN, NISA, LS-DYNA and others. The finite element program considered for this study is ANSYS. 


\section{A. General Principles of Blast Phenomena}

In general, the load from the explosions is in the form of pressure. This can be analyzed by using the pressure load methods or detonation simulation methods. From the recommendations of BIS: 4991-1968 (15) "Criteria for blast load resistant design of structures for explosions above ground", it is noted that, due to the static loads i.e., dead loads and live loads, the structural members are exposed to detonation pressure which are required to resist the applied forces by means of internal stresses developed in them.

However, the effective loads due to blast, for which self-resistance should be developed in the member would depend upon the nonlinear properties of the members. Longer the natural time period of the member, smaller is the effective load for design.

Permitting plastic deformations, which increases the energy absorption, has the advantage that the effective time period of the structural elements such as beams, columns and slabs is extended, thereby reducing the effective load for its design. The most serious detonations are on the front elevation of a structure where in the buildings are oriented with the face normal to the path of propagation of wave as reported in the BIS code (15). However, due to the lack of recognized orientation of future explosions, each side of the building should be considered as the facade of the building. When the blast field surrounds the structure, the variation of pressure that is more than the atmospheric pressure takes place on the front and the rear of structure, which tends to tilt and drift. Surface explosions that are short duration with a large amplitude and high frequency excitations induce the surface blasting or ground bursts. As the blast wave travels away from the source, the pressure amplitude decreases, and the duration of the blast load increases.

The type of blasting considered for this study is the blast excitation at a setback distance that is called as standoff distance, which is illustrated in Figure. 1 (10). The standoff distance cannot be predicted in any real life terrorist attacks and at the same time, it is impossible to quantify the charge weight of bomb being used. As recommended in the building bylaws, the standoff distance of explosion or the setback for Ground +3 commercial building is considered for the study.

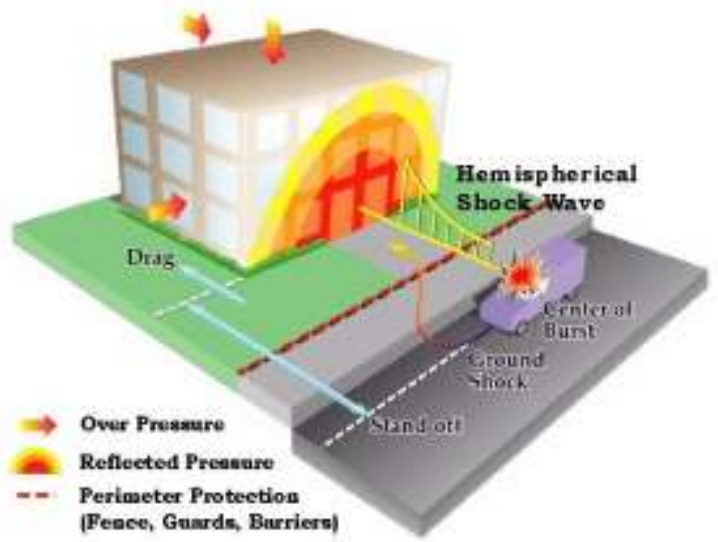

Figure 1. Surface Blast Wave with Standoff Distance

Over expansion at the center of the blast generates a vacuum in the source region and a reversal of gas motion occur. The negative pressure region expands outward, causing a negative pressure (below ambient), which trails the positive phase. The pressure of negative phase is usually below the magnitude (absolute value), but has longer duration than the positive phase. Burst phase loads are more positively charged then the negative phase coherence, which is often ignored as reported by $\mathrm{T}$. Ngo and P.Mendis et al (10), which is illustrated in Figure 2. Dasari Sudheer Kumar and Pallavi Rai (4) have explained about earth explosion or gust that breaks down hardened structures like bunkers, missile silos, locks, springs, etc. They cause mushroom cloud. As the detonation takes place at ground level, a lot of facilities are required to be shielded from each other from that of the previous damage that is less when compared to the air blast.

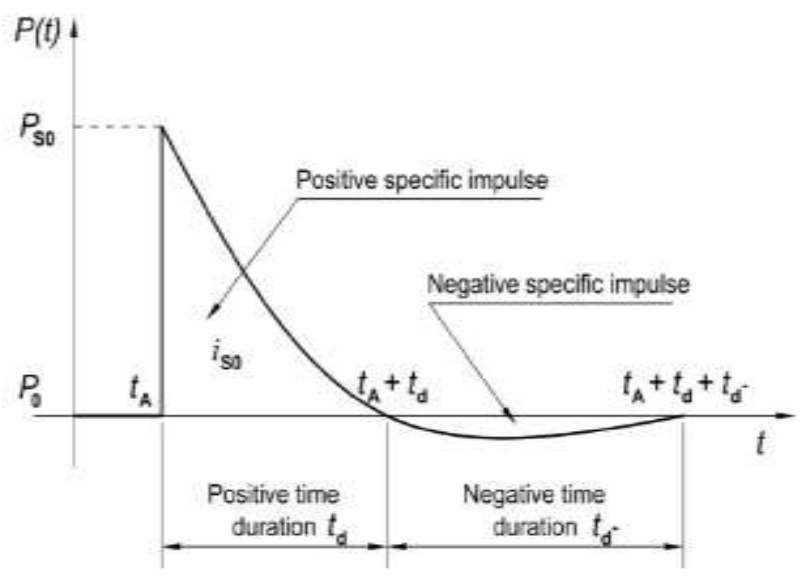

Figure 2. Pressure - time history graph 


\section{B. Structural Response To Blast}

\section{Loading}

Based on the manmade explosions that have occurred around the world, an attempt is made to analyze the structure that is able to resist the extreme bursts in a very short time on the structural members and its joints. The deflection and the corresponding strains that are greater than the allowable strains are investigated.

The complexity involves in analyzing the dynamic response of the structure loaded with the blast load and the influence of high strains, nonlinear behavior of inelastic material, calculation of blast load uncertainty and time dependent deformation. Therefore, to simplify the analysis, a number of assumptions on structure and load responses have been widely accepted. The permissible deflections in the structures are usually in the plastic range of materials. A large quantity of excitation pressure will be absorbed by the structure during the action of explosion, especially by concrete, thus reducing the design strength required significantly below the normal by conventional structural design standard within the elastic range of materials.

\section{High Strains (HS) and Lateral Deflections (LD)}

Under extremely dynamic vibrant conditions, strains depend upon the response of the material and high levels of hydrostatic loads, resulting in the behavior of the material to be extremely varying from what is noticed in normal quasi static loadings. When the rate of loading is high, the mechanical response of a material is generally different from that of normal loads, in which case, rates of loading dependence is observed for approximately the inelastic materials such as concrete. Concrete also exhibits an enigmatic phenomenon and improves properties against resistance as soon as concrete is loaded at very high rates by adding some of the composite materials such as fibers or designing concrete for higher grades.

Carter. C (14) the member ductility based on the stress strain curve results in the reinforcing steel undergoing elongation without rise in stress by about 10 to 15 times, the extent required to reach yielding point. The stress value then increase in hardening range of strain until a total elongation of approximately $20 \%$ to $30 \%$ is achieved. This response has benefits beyond routine design level forces for resisting the effects of a blast.
Ductility ratio defined as the maximum deflection to the elastic deflection is generally used for interpretation for this effect.

\section{Steel Fibered Reinforced Concrete}

Research has shown that the addition of steel fibers in concrete mix improves ductility, hardness, tensile strength, and compressive strength, Mohammed Alias Yusuf (9). Why would we want to add such fibers for concrete? Plain cement concrete is a brittle material and with a low tensile strength and less strain capacity. Fibers distributed randomly into the concrete give the flexibility of division by Hong Hao, Gang Chen et al (5). Reinforced steel fiber will be joined by those most accessible information fuse under various evaluations of cement for different needs. The properties of hooked end steel fibres are referred from Jeetmull Jaichandlall Pvt Ltd Chennai with aspect ratio of 50. The length of steel fibres used is $50 \mathrm{~mm}$ and diameter is $1 \mathrm{~mm}$.

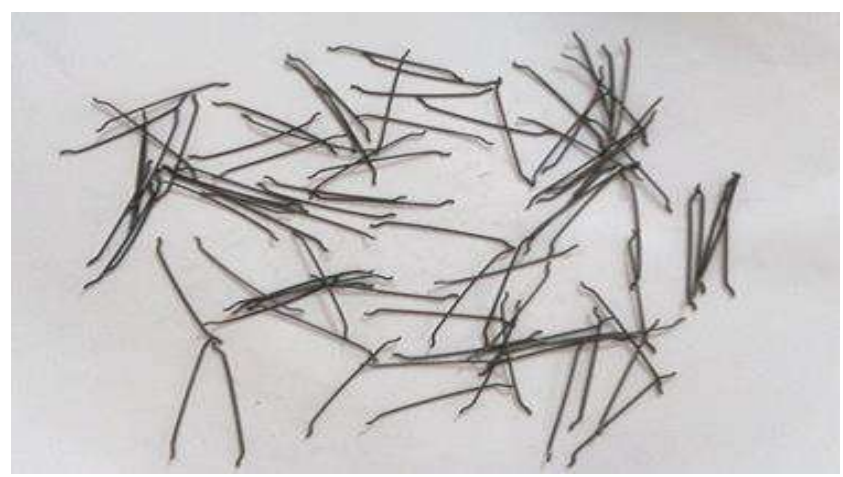

Figure 3. Hooked end steel fibres of aspect ratio 50

\section{Methodology}

The research was carried out to determine the passive structural response of commercial $\mathrm{G}+3$ building by using different percentage of fibers and also to determine high strains and lateral deflections at different levels of the building and the results compared with the structure without steel fibers at the same standoff distances. Finite element model for the surface blast load analysis and the behavior of structure for normal RC structure with static loads and RC structure with different percentages of steel fibers with $0.5 \%, 1 \%, 1.5 \%$ and $2 \%$ subjected to blast loads by considering different standoff distances (Z) and varying charge weights $(\mathrm{W})$ of explosion are developed. Through the experimental work the density, compressive 
strength, Poisson's ratio and elastic modulus was determined for M25 concrete and with addition of steel fibers $0.5,1,1.5$ and $2 \%$ respectively. Study was undertaken to analyze the finite element model of $\mathrm{G}+3$ storey commercial building for the static loads and dynamic loads such as blast with a setback of $3 \mathrm{~m}, 6 \mathrm{~m}$ and $9 \mathrm{~m}$ as standoff distance and the results compared. The blast equivalent over pressure from the blast waves as blast loads was determined to apply to the structure to assess the high strains and lateral deflections. The blast loads with steel fibers and with charge weights of 5, 6, 8 $\mathrm{kg}$ of TNT was considered for the study.

\section{v. Analysis}

The experimental investigation was mainly carried out in two phases; the first phase was in casting and testing of concrete specimens with M25 grade of concrete and in addition of steel fibers. Tests were conducted on basic materials, concrete mix proportions with steel fibers. Tests were also conducted on fresh concrete and for hardened concrete after 28 days of curing for the inputs such as density, Poisson's ratio and Young's modulus.

The second phase of the work was to obtain the blast overpressure and time duration parameters based on the typical blast wave propagation illustrated in Fig. 2. The calculation of Peak overpressure and time duration of explosion based on literatures was considered and determined for three charge weights such as 5,6 and $8 \mathrm{~kg}$ of TNT with three standoff distances $3 \mathrm{~m}, 6 \mathrm{~m}$ and $9 \mathrm{~m}$ respectively as shown in the Table. 1, 2 and 3. The blast parameters were achieved by the graphical representation of confining to TM5-1300 as shown in Figure. 4.

Parameters based on the typical blast wave phenomena are as follows: charge weight of TNT in $\mathrm{kg}$, scaled distance ' $Z$ ', peak reflected pressure ' $\mathrm{P}_{\mathrm{ro}}$ ', blast overpressure ' $\mathrm{P}_{\mathrm{so}}$ ', scaled arrival time ' $\mathrm{t}_{\mathrm{a}}$ ', positive phase duration ' $\mathrm{t}_{\mathrm{o}}$ ', total duration ' $\mathrm{t}_{\mathrm{d}}$ '.

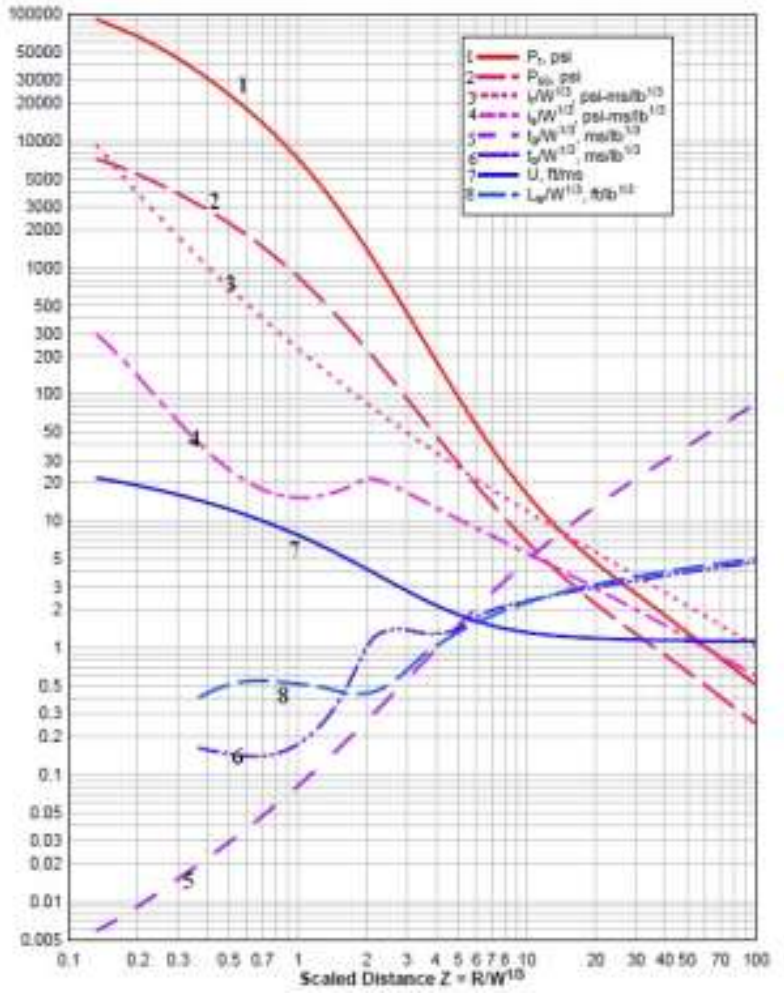

Figure 4. Blast Parameters from Graphical Representation Confining to TM5-1300

TABLE I. BLAST LOAD PARAMETERS WITH CHARGE WEIGHTS OF 5KG, 6KG, 8KG AND STANDOFF AS 3M

\begin{tabular}{|c|c|c|c|c|c|c|}
\hline $\begin{array}{l}\text { TNT } \\
\text { (kg) }\end{array}$ & $\begin{array}{c}' Z^{\prime} \\
(\mathrm{m} / \mathrm{kg})^{1 / 3}\end{array}$ & $\begin{array}{c}\text { 'P } \mathbf{P}_{\mathbf{r}}^{\prime} \\
(\mathbf{M p a})\end{array}$ & $\begin{array}{c}\text { 'P } \mathbf{P}_{\mathrm{so}}{ }^{\prime} \\
(\mathrm{Mpa})\end{array}$ & $\begin{array}{l}{ }^{6} \mathbf{t}_{\mathrm{a}}{ }^{\prime} \\
(\mathrm{Sec})\end{array}$ & $\begin{array}{l}{ }^{\prime} t_{0}{ }^{\prime} \\
\text { (Sec) }\end{array}$ & $\begin{array}{c}'{ }^{\prime} t_{d} ' \\
(\text { Sec })\end{array}$ \\
\hline 5 & 4.459 & 0.965 & 0.275 & 0.0353 & 0.0331 & 0.0684 \\
\hline 6 & 4.198 & 1.310 & 0.344 & 0.0234 & 0.0351 & 0.0586 \\
\hline 8 & 3.819 & 1.379 & 0.448 & 0.018 & 0.0353 & 0.0515 \\
\hline
\end{tabular}

\begin{tabular}{|c|c|c|c|c|c|c|}
\hline $\begin{array}{l}\text { TNT } \\
\text { (kg) }\end{array}$ & $\begin{array}{c}\mathbf{C}^{\prime} \\
(\mathbf{m} / \mathbf{k g})^{1 / 3}\end{array}$ & $\begin{array}{c}\text { 'P } \mathbf{P}_{\mathbf{r}}^{\prime} \\
\text { (Mpa) }\end{array}$ & $\begin{array}{c}\text { 'P }{ }_{\text {so' }} \\
\text { (Mpa) }\end{array}$ & $\begin{array}{c}{ }^{\prime} \mathbf{t}_{\mathrm{a}}{ }^{\prime} \\
(\mathrm{Sec})\end{array}$ & $\begin{array}{c}{ }^{\prime} \mathbf{t}_{\mathbf{o}} \\
(\mathbf{S e c})\end{array}$ & $\begin{array}{c}{ }^{\prime} \mathbf{t}_{\mathrm{d}}{ }^{\prime} \\
(\mathbf{S e c})\end{array}$ \\
\hline 5 & 8.95 & 0.130 & 0.055 & 0.0101 & 0.0048 & 0.0149 \\
\hline 6 & 8.43 & 0.144 & 0.062 & 0.0093 & 0.0053 & 0.0150 \\
\hline 8 & 7.37 & 0.172 & 0.080 & 0.0070 & 0.0056 & 0.0130 \\
\hline
\end{tabular}
WEIGHTS OF 5KG, 6KG, 8KG AND STANDOFF AS 9M

\begin{tabular}{|c|c|c|c|c|c|c|}
\hline $\begin{array}{l}\text { TNT } \\
(\mathrm{kg})\end{array}$ & $\begin{array}{c}' \mathbf{Z}^{\prime} \\
(\mathbf{m} / \mathbf{k g})^{1 / 3}\end{array}$ & $\begin{array}{c}{ }^{'} \mathbf{P}_{\mathbf{r}}{ }^{\prime} \\
(\mathbf{M p a})\end{array}$ & $\begin{array}{c}\text { 'P } \mathbf{P}_{\mathrm{so}}{ }^{\prime} \\
(\mathbf{M p a})\end{array}$ & $\begin{array}{c}{ }^{'} t_{\mathrm{a}}{ }^{\prime} \\
(\mathrm{Sec})\end{array}$ & $\begin{array}{c}{ }^{\prime} t_{0}{ }^{\prime} \\
\text { (Sec) }\end{array}$ & $\begin{array}{c}{ }^{' t_{\mathrm{d}}} \\
(\mathrm{Sec})\end{array}$ \\
\hline 5 & 13.375 & 0.068 & 0.034 & 0.1324 & 0.0551 & 0.187 \\
\hline 6 & 12.59 & 0.089 & 0.041 & 0.1306 & 0.0539 & 0.184 \\
\hline 8 & 11.45 & 0.117 & 0.048 & 0.1288 & 0.0515 & 0.180 \\
\hline
\end{tabular}




\section{A. Blast Loads on the}

\section{Structure}

To determine blast wave parameters from a surface blast.

The parameters for $5 \mathrm{~kg}$ of TNT and $3 \mathrm{~m}$ standoff distance:

$\mathrm{Z}=3 /(5)^{1 / 3} \mathrm{~m} /(\mathrm{kg})^{1 / 3}$

$\mathrm{Z}=4.459 \mathrm{ft} . / \mathrm{lbs}^{1 / 3}$

Figure 4. Shows Graph confining to TM5-1300.

Peak reflected overpressure $\mathrm{P}_{\mathrm{r}}=140 \mathrm{psi}=0.140 \mathrm{ksi}$ $=0.140$ X $6.895=0.965 \mathrm{Mpa}$

Peak blast equivalent overpressure $\mathrm{P}_{\text {so }}=40 \mathrm{psi}=$ $0.040 \mathrm{ksi}=0.040 \times 6.895=0.275 \mathrm{Mpa}$

$\mathrm{t}_{\mathrm{a}} / \mathrm{W}^{1 / 3}=4.540 \mathrm{psi} \mathrm{ms} / \mathrm{lb}^{1 / 3}=4.540 \mathrm{X}(11.02)^{1 / 3}=$ 3.53 milliseconds

$\mathrm{t}_{\mathrm{o}} / \mathrm{W}^{1 / 3}=2.195 \mathrm{psi} \mathrm{ms} / \mathrm{lb}^{1 / 3}=2.195 \mathrm{X}(11.02)^{1 / 3}=$ 3.31 milliseconds

$\mathrm{t}_{\mathrm{d}}=\mathrm{t}_{\mathrm{a}}+\mathrm{t}_{\mathrm{o}}=3.53+3.31=6.84$ milliseconds.

The parameters for $6 \mathrm{~kg}$ of TNT and $3 \mathrm{~m}$ standoff distance:

$\mathrm{Z}=3 /(6)^{1 / 3} \mathrm{~m} /(\mathrm{kg})^{1 / 3}$

$\mathrm{Z}=4.198 \mathrm{ft} . / \mathrm{lbs}^{1 / 3}$

Figure 4. Shows Graph confining to TM5-1300.

Peak reflected over pressure $\mathrm{P}_{\mathrm{r}}=190 \mathrm{psi}=0.190 \mathrm{ksi}$ $=0.190$ X $6.895=1.310 \mathrm{Mpa}$

Peak blast equivalent over pressure $\mathrm{P}_{\mathrm{so}}=50 \mathrm{psi}=$ $0.050 \mathrm{ksi}=0.050$ X $6.895=0.344 \mathrm{Mpa}$.

$\mathrm{t}_{\mathrm{a}} / \mathrm{W}^{1 / 3}=1.0 \mathrm{~ms} / \mathrm{lb}^{1 / 3}=1.0 \mathrm{X}(13.22)^{1 / 3}=2.344$ milliseconds.

$\mathrm{t}_{\mathrm{o}} / \mathrm{W}^{1 / 3}=1.5 \mathrm{~ms} / \mathrm{lb}^{1 / 3}=1.5 \mathrm{X}(13.22)^{1 / 3}=3.516$ milliseconds

$\mathrm{t}_{\mathrm{d}}=\mathrm{t}_{\mathrm{a}}+\mathrm{t}_{\mathrm{o}}=2.344+3.516=5.86$ milliseconds.
The parameters for $8 \mathrm{~kg}$ of TNT and $3 \mathrm{~m}$ standoff distance:

$\mathrm{Z}=3 /(8)^{1 / 3} \mathrm{~m} /(\mathrm{kg})^{1 / 3}$

$\mathrm{Z}=3.819 \mathrm{ft} . / \mathrm{lbs}^{1 / 3}$

Figure 4. Shows Graph confining to TM5-1300.

Peak reflected over pressure $\mathrm{P}_{\mathrm{r}}=200 \mathrm{psi}=0.200 \mathrm{ksi}$ $=0.200 \times 6.895=1.379 \mathrm{Mpa}$

Peak blast equivalent over pressure $\mathrm{P}_{\mathrm{so}}=65 \mathrm{psi}=$ $0.065 \mathrm{ksi}=0.065$ X $6.895=0.448 \mathrm{Mpa}$.

$\mathrm{t}_{\mathrm{a}} / \mathrm{W}^{1 / 3}=0.7 \mathrm{~ms} / \mathrm{lb}^{1 / 3}=0.7 \mathrm{X}(17.63)^{1 / 3}=1.803$ milliseconds.

$\mathrm{t}_{\mathrm{o}} / \mathrm{W}^{1 / 3}=1.3 \mathrm{~ms} / \mathrm{lb}^{1 / 3}=1.3 \mathrm{X}(17.63)^{1 / 3}=3.35$ milliseconds

$\mathrm{t}_{\mathrm{d}}=\mathrm{t}_{\mathrm{a}}+\mathrm{t}_{\mathrm{o}}=1.803+3.35=5.15$ milliseconds

The parameters for $5 \mathrm{~kg}$ of TNT and $6 \mathrm{~m}$ standoff distance:

$\mathrm{Z}=6 /(5)^{1 / 3} \mathrm{~m} /(\mathrm{kg})^{1 / 3}$

$\mathrm{Z}=8.95 \mathrm{ft} / \mathrm{lbs}^{1 / 3}$

Figure 4. Shows Graph confining to TM5-1300.

Peak reflected overpressure $\mathrm{P}_{\mathrm{r}}=20 \mathrm{psi}=0.02 \mathrm{ksi}$ $=0.02 \times 6.895=0.137 \mathrm{Mpa}$

Peak blast equivalent overpressure $\mathrm{P}_{\mathrm{so}}=8 \mathrm{psi}=$ $0.008 \mathrm{ksi}=0.008 \times 6.895=0.055 \mathrm{Mpa}$

$\mathrm{t}_{\mathrm{a}} / \mathrm{W}^{1 / 3}=4.540 \mathrm{~ms} / \mathrm{lb}^{1 / 3}=4.540 \mathrm{X}(11.02)^{1 / 3}=$ 10.104 milliseconds

$\mathrm{t}_{\mathrm{o}} / \mathrm{W}^{1 / 3}=2.195 \mathrm{~ms} / \mathrm{lb}^{1 / 3}=2.195 \mathrm{X}(11.02)^{1 / 3}=4.88$ milliseconds

$\mathrm{t}_{\mathrm{d}}=\mathrm{t}_{\mathrm{a}}+\mathrm{t}_{\mathrm{o}}=10.104+4.88=14.98$ milliseconds.

The parameters for $6 \mathrm{~kg}$ of TNT and $6 \mathrm{~m}$ standoff distance:

$\mathrm{Z}=6 /(6)^{1 / 3} \mathrm{~m} /(\mathrm{kg})^{1 / 3}$

$\mathrm{Z}=8.16 \mathrm{ft} . / \mathrm{lbs}^{1 / 3}$

Figure 4. Shows Graph confining to TM5-1300. 
Peak reflected over pressure $\mathrm{P}_{\mathrm{r}}=20.75 \mathrm{psi}=$ $0.02075 \mathrm{ksi}=0.02075 \times 6.895=0.144 \mathrm{Mpa}$

Peak blast equivalent over pressure $\mathrm{P}_{\mathrm{so}}=907 \mathrm{psi}=$ $0.00907 \mathrm{ksi}=0.00907$ X $6.895=0.0625 \mathrm{Mpa}$.

$\mathrm{t}_{\mathrm{a}} / \mathrm{W}^{1 / 3}=3.95 \mathrm{~ms} / \mathrm{lb}^{1 / 3}=3.95 \mathrm{X}(13.22)^{1 / 3}=9.33$ milliseconds.

$\mathrm{t}_{\mathrm{o}} / \mathrm{W}^{1 / 3}=2.41 \mathrm{~ms} / \mathrm{lb}^{1 / 3}=2.41 \mathrm{X}(13.22)^{1 / 3}=5.69$ milliseconds

$\mathrm{t}_{\mathrm{d}}=\mathrm{t}_{\mathrm{a}}+\mathrm{t}_{\mathrm{o}}=9.33+5.39=15.04$ milliseconds.

The parameters for $8 \mathrm{~kg}$ of TNT and $6 \mathrm{~m}$ standoff distance:

$\mathrm{Z}=8 /(6)^{1 / 3} \mathrm{~m} /(\mathrm{kg})^{1 / 3}$

$\mathrm{Z}=7.37 \mathrm{ft} . / \mathrm{lbs}^{1 / 3}$

Figure 4. Shows Graph confining to TM5-1300.

Peak reflected overpressure $\mathrm{P}_{\mathrm{r}}=25 \mathrm{psi}=0.025 \mathrm{ksi}$ $=0.025 * 6.895=0.172 \mathrm{Mpa}$

Peak blast equivalent overpressure $\mathrm{P}_{\mathrm{so}}=11.62 \mathrm{psi}=$ $0.01162 \mathrm{ksi}=0.01162 \times 6.895=0.0801 \mathrm{Mpa}$

$\mathrm{t}_{\mathrm{a}} / \mathrm{W}^{1 / 3}=2.96 \mathrm{~ms} / \mathrm{lb}^{1 / 3}=2.96 \mathrm{X}(17.63)^{1 / 3}=7.70$ milliseconds

$\mathrm{t}_{\mathrm{o}} / \mathrm{W}^{1 / 3}=2.063 \mathrm{~ms} / \mathrm{lb}^{1 / 3}=2.063 \mathrm{X}(17.63)^{1 / 3}=$ 5.368 milliseconds

$\mathrm{t}_{\mathrm{d}}=\mathrm{t}_{\mathrm{a}}+\mathrm{t}_{\mathrm{o}}=7.70+5.368=13.06$ milliseconds.

The parameters for $5 \mathrm{~kg}$ of TNT and $9 \mathrm{~m}$ standoff distance:

$\mathrm{Z}=9 /(5)^{1 / 3} \mathrm{~m} /(\mathrm{kg})^{1 / 3}$

$\mathrm{Z}=13.375 \mathrm{ft} . / \mathrm{lbs}^{1 / 3}$

Figure 4. Shows Graph confining to TM5-1300.

Peak reflected over pressure $\mathrm{P}_{\mathrm{r}}=10 \mathrm{psi}=0.010 \mathrm{ksi}$ $=0.010$ X $6.895=0.0689 \mathrm{Mpa}$

Peak blast equivalent over pressure $\mathrm{P}_{\mathrm{so}}=5 \mathrm{psi}=$ $0.005 \mathrm{ksi}=0.005$ X $6.895=0.0344 \mathrm{Mpa}$.

$\mathrm{t}_{\mathrm{a}} / \mathrm{W}^{1 / 3}=6 \mathrm{~ms} / \mathrm{lb}^{1 / 3}=6 \mathrm{X}(11.02)^{1 / 3}=13.24$ milliseconds. $\mathrm{t}_{\mathrm{o}} / \mathrm{W}^{1 / 3}=2.5 \mathrm{~ms} / \mathrm{lb}^{1 / 3}=2.5 \mathrm{X}(11.02)^{1 / 3}=5.51$ milliseconds

$\mathrm{t}_{\mathrm{d}}=\mathrm{t}_{\mathrm{a}}+\mathrm{t}_{\mathrm{o}}=13.24+5.51=18.75$ milliseconds.

The parameters for $6 \mathrm{~kg}$ of TNT and $9 \mathrm{~m}$ standoff distance:

$\mathrm{Z}=9 /(6)^{1 / 3} \mathrm{~m} /(\mathrm{kg})^{1 / 3}$

$\mathrm{Z}=12.59 \mathrm{ft} . / \mathrm{lbs}^{1 / 3}$

Figure 4. Shows Graph confining to TM5-1300.

Peak reflected over pressure $\mathrm{P}_{\mathrm{r}}=13 \mathrm{psi}=0.013 \mathrm{ksi}$ $=0.013$ X $6.895=0.0896 \mathrm{Mpa}$

Peak blast equivalent over pressure $\mathrm{P}_{\mathrm{so}}=6 \mathrm{psi}=$ $0.006 \mathrm{ksi}=0.006$ X $6.895=0.0413 \mathrm{Mpa}$.

$\mathrm{t}_{\mathrm{a}} / \mathrm{W}^{1 / 3}=6 \mathrm{~ms} / \mathrm{lb}^{1 / 3}=6 \mathrm{X}(13.22)^{1 / 3}=14.06$ milliseconds.

$\mathrm{t}_{\mathrm{o}} / \mathrm{W}^{1 / 3}=2.3 \mathrm{~ms} / \mathrm{lb}^{1 / 3}=2.3 \mathrm{X}(13.22)^{1 / 3}=5.39$ milliseconds

$\mathrm{t}_{\mathrm{d}}=\mathrm{t}_{\mathrm{a}}+\mathrm{t}_{\mathrm{o}}=12.88+5.15=18.0$ milliseconds.

The parameters for $8 \mathrm{~kg}$ of TNT and $9 \mathrm{~m}$ standoff distance:

$\mathrm{Z}=9 /(8)^{1 / 3} \mathrm{~m} /(\mathrm{kg})^{1 / 3}$

$\mathrm{Z}=11.45 \mathrm{ft} . / \mathrm{lbs}^{1 / 3}$

Figure 4. Shows Graph confining to TM5-1300.

Peak reflected over pressure $\mathrm{P}_{\mathrm{r}}=17 \mathrm{psi}=0.017 \mathrm{ksi}$ $=0.017 \times 6.895=0.117 \mathrm{Mpa}$

Peak blast equivalent over pressure $\mathrm{P}_{\mathrm{so}}=7 \mathrm{psi}=$ $0.007 \mathrm{ksi}=0.007$ X $6.895=0.048 \mathrm{Mpa}$.

$\mathrm{t}_{\mathrm{a}} / \mathrm{W}^{1 / 3}=5.0 \mathrm{~ms} / \mathrm{lb}^{1 / 3}=5.0 \mathrm{X}(17.63)^{1 / 3}=12.88$ milliseconds.

$\mathrm{t}_{\mathrm{o}} / \mathrm{W}^{1 / 3}=2.0 \mathrm{~ms} / \mathrm{lb}^{1 / 3}=2.0 \mathrm{X}(17.63)^{1 / 3}=5.15$ milliseconds

$\mathrm{t}_{\mathrm{d}}=\mathrm{t}_{\mathrm{a}}+\mathrm{t}_{\mathrm{o}}=12.88+5.15=18.03$ milliseconds.

The charge weights of $5 \mathrm{~kg}, 6 \mathrm{~kg}$ and $8 \mathrm{~kg}$ of TNT was considered for this study as blast load, with standoff distances of $3 \mathrm{~m}, 6 \mathrm{~m}$ and $9 \mathrm{~m}$. Peak excitation pressure and the time duration 
parameters based on the distance from explosion to the structure, and with reference to charge weights the blast load parameters such as scaled distance, reflected pressure from shock wave front, blast equivalent overpressure and time parameters scaled arrival time, positive phase duration and total duration of explosions were calculated and represented in the typical blast wave phenomena (TBP) as illustrated in Fig. 5, Fig. 6, Fig. 7, Fig. 8, Fig. 9, Fig. 10, Fig. 11, Fig. 12, Fig. 13 respectively.

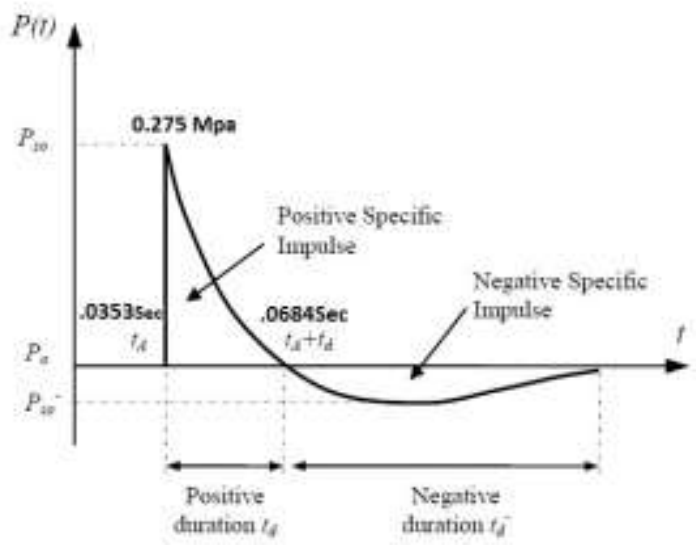

Figure 5. TBP of $5 \mathrm{~kg}$ TNT \& $3 \mathrm{~m}$ Standoff distance

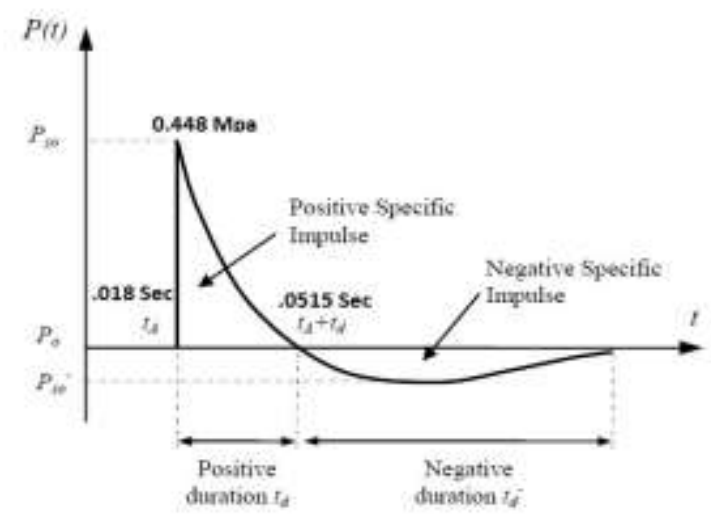

Figure 6. TBP of $6 \mathrm{~kg}$ TNT \& $3 \mathrm{~m}$ Standoff distance

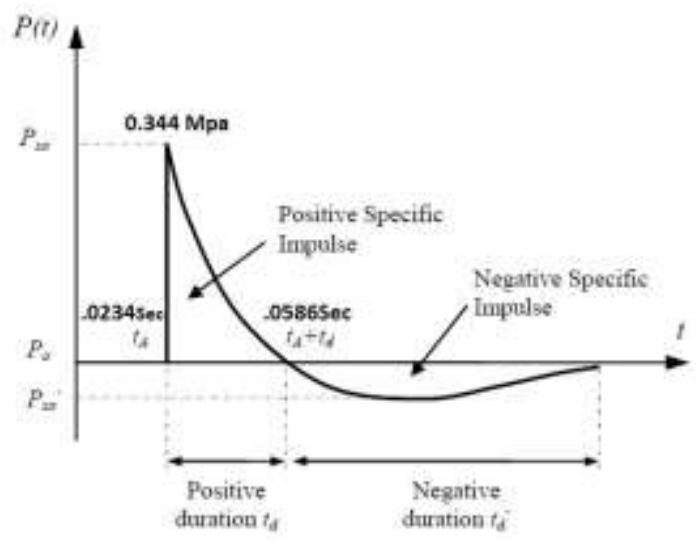

Figure 7. TBP of $8 \mathrm{~kg}$ TNT \& 3m Standoff distance

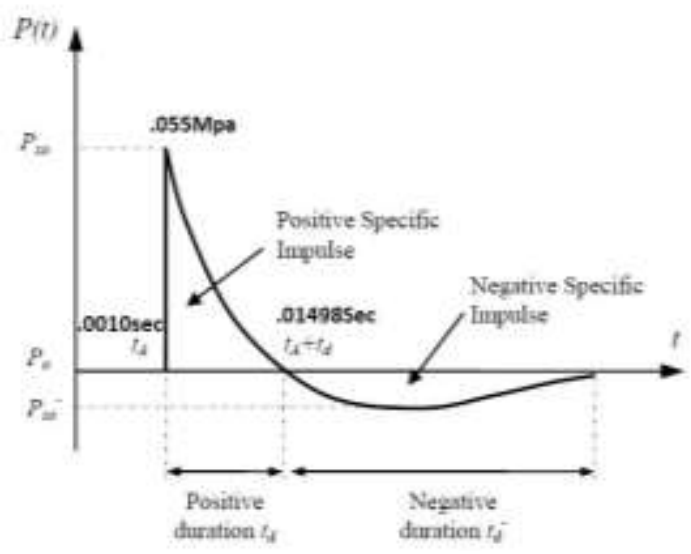

Figure 8 . TBP of $5 \mathrm{~kg}$ TNT \& $6 \mathrm{~m}$ Standoff distance

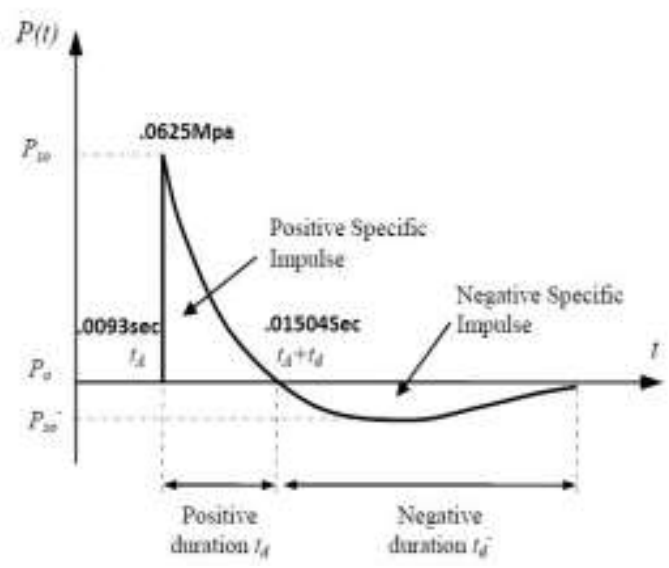

Figure 9. TBP of $6 \mathrm{~kg}$ TNT \& $6 \mathrm{~m}$ Standoff distance

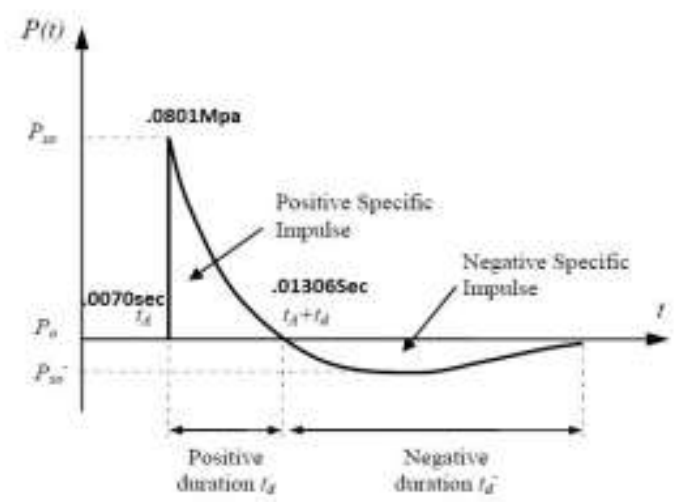

Figure 10. TBP of $8 \mathrm{~kg}$ TNT \& $6 \mathrm{~m}$ Standoff distance 


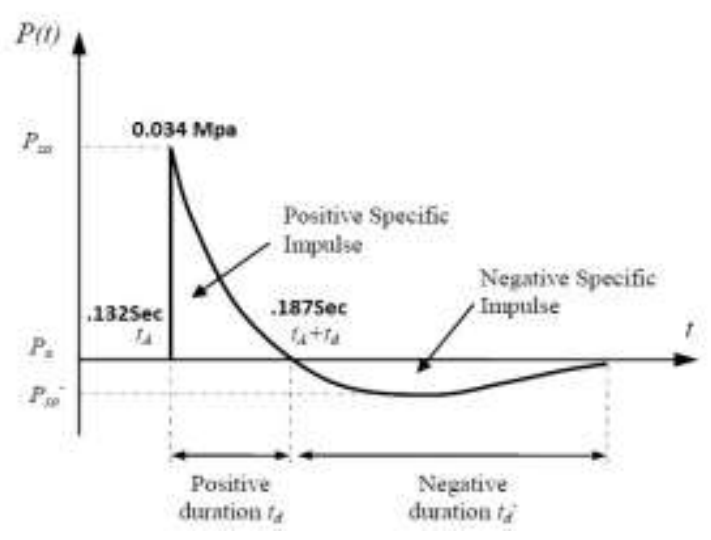

Figure 11. TBP of $5 \mathrm{~kg}$ TNT \& 9m Standoff distance

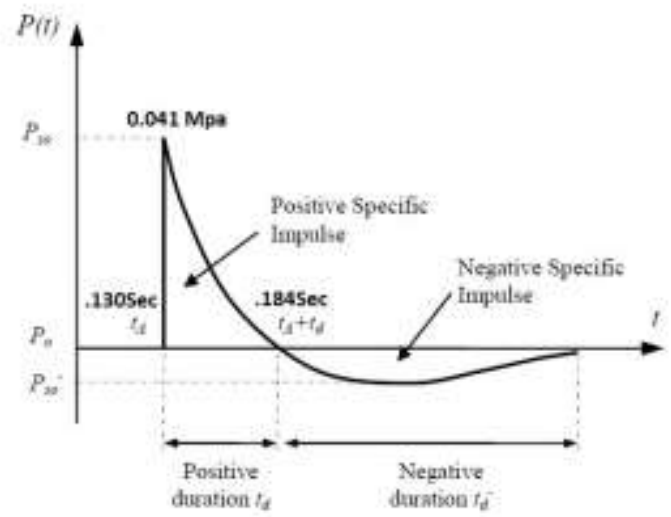

Figure 12. TBP of $6 \mathrm{~kg}$ TNT \& 9m Standoff distance

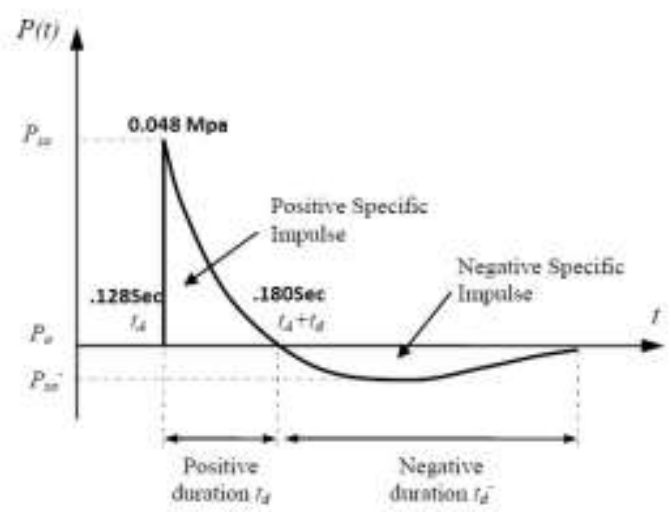

Figure 13. TBP of $8 \mathrm{~kg}$ TNT \& 9m Standoff distance

The tests on hardened concrete were the standard test method for the static compression, concrete Poisson's ratio, elastic modulus, ratio of strain value and the stress for the hardened concrete at any age. This rule also provides that the elastic modulus is applicable to the range of the normal operating voltage of 0 to $40 \%$ of the final strength of the concrete. The modulus of elasticity is often used for reinforced and non-reinforced structural elements. The tests conducted on hardened concrete were for Poisson's ratio and modulus of elasticity by noting the compressive strain with respect to compressive stress at every $10 \mathrm{kN}$ load increment and material properties for M25 grade of concrete and M25 concrete with steel fibers of 0.5 , 1.0, 1.5 and $2 \%$ variation as illustrated in Table. 4 .

\section{TABLE IV. MATERIAL PROPERTIES OF CONCRETE SPECIMENS}

\begin{tabular}{|c|c|c|c|c|}
\hline $\begin{array}{c}\text { Grade of } \\
\text { Concrete }\end{array}$ & $\begin{array}{c}\text { Poison's } \\
\text { ratio }\end{array}$ & $\begin{array}{c}\text { Young's } \\
\text { Modulus } \\
\left(\mathbf{N} / \mathbf{m m}^{2}\right)\end{array}$ & $\begin{array}{c}\text { Material's } \\
\text { Density } \\
\left(\mathbf{K N} / \mathbf{m}^{3}\right)\end{array}$ & $\begin{array}{c}\text { Coefficient } \\
\text { of Thermal } \\
\text { Expansion }\end{array}$ \\
\hline $\mathrm{M} 25$ & 0.18 & 26070 & 25 & $10^{-6} \%^{\circ} \mathrm{c}$ \\
\hline $\mathrm{M} 25+0.5 \%$ & 0.23 & 27386 & 26.1 & $10^{-6} \%^{\mathrm{c}}$ \\
\hline $\mathrm{M} 25+1 \%$ & 0.235 & 28995 & 27.4 & $10^{-6} \%^{\mathrm{o}} \mathrm{c}$ \\
\hline $\mathrm{M} 25+1.5 \%$ & 0.25 & 29568 & 27.1 & $10^{-6} \%^{\mathrm{o}} \mathrm{c}$ \\
\hline $\mathrm{M} 25+2 \%$ & 0.26 & 30000 & 27.105 & $10^{-6} \%^{\mathrm{c}} \mathrm{c}$ \\
\hline
\end{tabular}

\section{A. Structure Modelling}

Modeling part of the structure was carried out using software PTC Creo 3.0 software. Firstly, the modeling of structural members such as beams, columns and slabs were drafted, modeled and then assembled. By using Creo 3.0 the structural elements were modeled in separate files and the assembly of the files executed. After the geometric modeling of columns was completed, the cross sectional dimensions were provided. The beams and slabs were modeled simultaneously. The columns with respect to the geometry and with respect to its major and minor axis were modeled at its respective orientations as illustrated in Figure. 14. The complete assembly of structural members

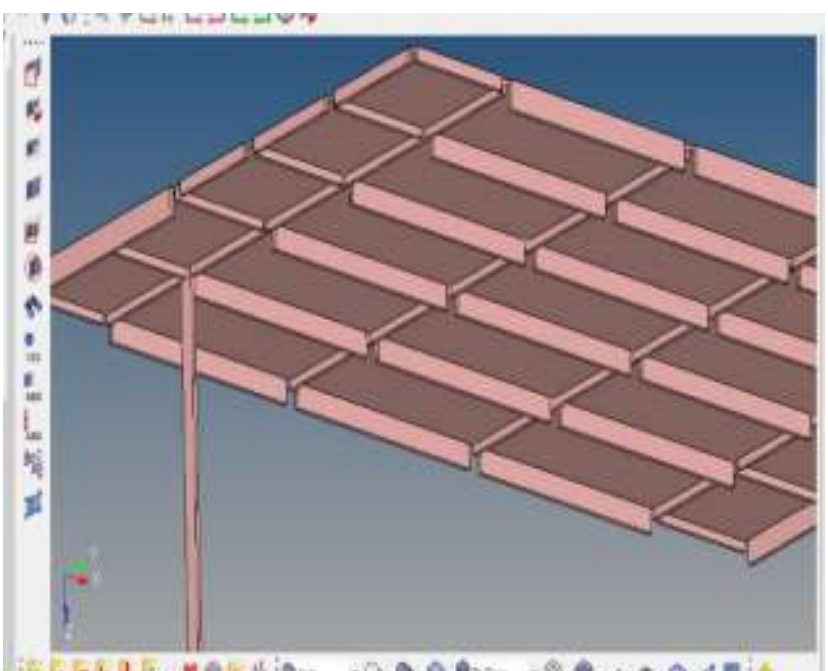

of the building model is illustrated in Figure. 15.

Figure 14. Assembly of column to slabs and beams 


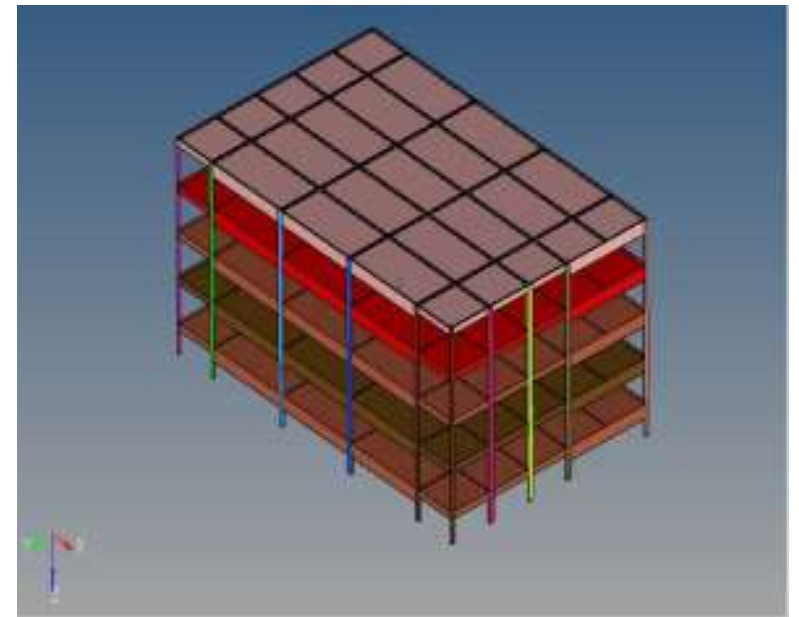

Figure 15. $\mathrm{G}+3$ building modelled in PTC CREO 3.0

\section{B. Finite Element Discretization}

The meshing of the structure was carried out using Hypermesh 14.0 software and Solid 65 element was considered for the concrete material. For this structure quad element was considered with a mesh size of $600 \mathrm{~mm}$ and an aspect ratio of $1: 1$. Compatibility at each beam column joint was checked. An eight-nodded quadrilateral element of $300 \mathrm{~mm}$ size was adopted for the geometric model. For discretization, ruled meshing was considered for the building model, it can be assigned by giving the mesh size as input based on the user and adopting a size which is more compatible and assigning it to the elements such as beams, columns and slabs. The compatibility of mesh is based on the elements shape and the size and purely based on the two or more elements. The actual discretization and the assembly of the structural members are illustrated in Figure. 16.

Figure 16. 8-noded quadrilateral element for meshing for

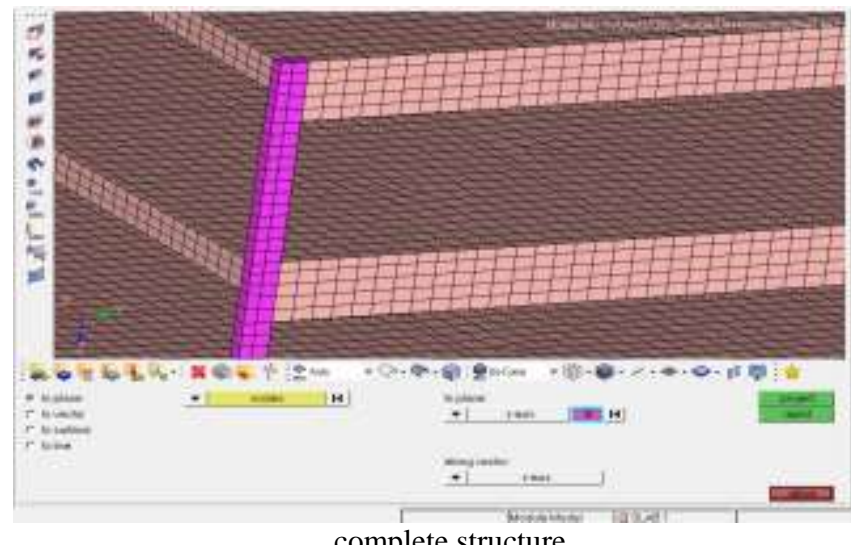

\section{Results and Discussions}

The high strains and lateral deflections for the results obtained from blast load analysis for the structure with M25 concrete and the structures with M25 steel fibered reinforced concrete with $0.5 \%$, $1 \%, 1.5 \%$ and $2 \%$ are compared. Structures are susceptible to damage from explosions, as the magnitudes of loads produced by blasts are significantly more than those of the design loads. The mechanical properties of steel fibered reinforced concrete improved compared to M25 concrete. The Poisson's ratio increased by $27.7 \%$, $30.56 \%, 38.89 \%$ and $44.4 \%$ and the modulus of elasticity increased by $5.05 \%, 11.22 \%, 13.42 \%$, and $15.07 \%$ respectively. The HS and LD's were determined and compared with the G+3 structure with M25 grade concrete and structure with steel fibers. The blast load analysis for the structure with 5,6 and $8 \mathrm{~kg}$ charge weight of TNT (Trinitrotoluene) at $3 \mathrm{~m}, 6 \mathrm{~m}$ and $9 \mathrm{~m}$ standoff distances respectively was performed. Comparisons of the results were made on the blast load analysis of $\mathrm{G}+3$ structure with M25 grade concrete and with inclusion $0.5,1,1.5$ and $2 \%$ of steel fibers at various standoff distances.

From the results obtained it was observed that the strain for M25 structure was 0.01592 at column grids $\mathrm{A}, \mathrm{B}$ and $\mathrm{F}$ at the level of ground and first storey of the building for $5 \mathrm{~kg}$ of TNT and $6 \mathrm{~m}$ standoff distance. Whereas the strains for M25 concrete structure with respect to blast load analysis of $5 \mathrm{~kg}$ TNT at $6 \mathrm{~m}$ standoff was observed as 0.004654 . The increase in the HSs compared to $3 \mathrm{~m}$ standoff distances is $216 \%$, which was observed at column grids $\mathrm{A}, \mathrm{B}$ and $\mathrm{F}$ at the base floor. This is illustrated in Figure. 17 that was more than the allowable strain of concrete 0.003 .

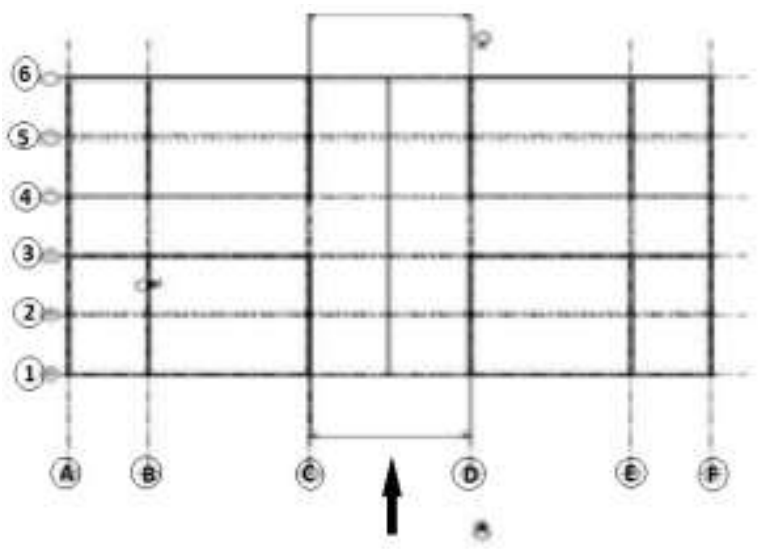

Figure 17. Structural Plan of the building 
By addition of steel fibers into the concrete matrix, the experimental results shows increase in modulus of elasticty and consequently the compressive strength when compared to the conventional M25 grade of concrete.

\section{A. $3 m$ standoff distance \& 5,6 and $8 \mathrm{~kg}$ of TNT}

The HSs at $3 \mathrm{~m}$ standoff distance and $5 \mathrm{~kg}$ of TNT with M25 grade of concrete and structure with $0.5 \%, 1 \%, 1.5 \%$ and $2 \%$ steel fibres were observed as $0.0159,0.0141,0.0136,0.0132$, and 0.0130 respectively. The HSs decreased by $10.95 \%$, $14.42 \%, 17.12 \%$ and $18.37 \%$ respectively when compared to the structure without fibres. At $3 \mathrm{~m}$ and $6 \mathrm{~kg}$ of TNT the HS's observed were 0.0197, $0.0175,0.0168,0.0163$ and 0.0161 and HS decreased by $10.95 \%, 14.42 \%, 16.97 \%$ and $17.89 \%$ respectively. At $3 \mathrm{~m}$ and $8 \mathrm{~kg}$ of TNT the HS's observed are $0.0254,0.0226,0.0217,0.0210$ and 0.020 respectively. The HS's decreased by $10.95 \%$, $14.42 \%, \quad 16.97 \%$ and $17.89 \%$ respectively compared to a structure without fibres. At $3 \mathrm{~m}$ and $8 \mathrm{~kg}$ of TNT with M25 grade of concrete and structure with $0.5 \%, 1 \%, 1.5 \%$ and $2 \%$ steel fibres the HS's observed were $0.0254,0.0226,0.0217$, 0.0210 and 0.0206 respectively. The HS's decreased by $10.95 \%, 14.41 \%, 16.98 \%$ and $17.89 \%$ when compared to the structures without fibres.

At $3 \mathrm{~m}$ standoff distance and $5 \mathrm{~kg}$ of TNT charge weight the structure with M25 grade of concrete and structures with $0.5 \%, 1 \%, 1.5 \%$ and $2 \%$ steel fibers, the LDs observed were $397.26 \mathrm{~mm}$, $347.49 \mathrm{~mm}, 333.6 \mathrm{~mm}, 321.09 \mathrm{~mm}$ and $315.6 \mathrm{~mm}$ respectively and corresponding decrease in the LDs were $12.53 \%, 16.02 \%, 19.17 \%$ and $20.68 \%$.

At $3 \mathrm{~m}$ standoff distance and $6 \mathrm{~kg}$ of TNT charge weight the conventional structure with M25 grade of concrete and structures with $0.5 \%, 1 \%$, $1.5 \%$ and $2 \%$ steel fibers, the LDs observed were $497.74 \mathrm{~mm}, 435.28 \mathrm{~mm}, 418.43 \mathrm{~mm}, 402.73 \mathrm{~mm}$ and $396.64 \mathrm{~mm}$ respectively and the corresponding decrease in LDs were $12.57 \%, 15.93 \%, 19.09 \%$ and $20.31 \%$ respectively.

At $3 \mathrm{~m}$ standoff distance and $8 \mathrm{~kg}$ of TNT charge weight the conventional structure with M25 grade of concrete and structures with $0.5 \%, 1 \%$, $1.5 \%$ and $2 \%$ steel fibers, the LDs observed were $649.19 \mathrm{~mm}, 567.85 \mathrm{~mm}, 545.75 \mathrm{~mm}, 525.27 \mathrm{~mm}$ and $517.33 \mathrm{~mm}$ respectively and the corresponding decrease in LDs observed was $12.54 \%, 15.93 \%$, $19.09 \%$ and $20.31 \%$ respectively.
Table 5. HIGH STRAINS AND LATERAL DEFLECTIONS FOR 3M STANDOFF STRUCTURE WITH \&WITHOUT FIBERS

\begin{tabular}{|c|c|c|c|}
\hline $\begin{array}{c}\text { Type of } \\
\text { structure }\end{array}$ & $\begin{array}{c}\text { Charge } \\
\text { weight } \\
\text { (kg) }\end{array}$ & $\begin{array}{c}\text { High } \\
\text { Strains }\end{array}$ & $\begin{array}{c}\text { Lateral } \\
\text { Deflections } \\
\text { (mm) }\end{array}$ \\
\hline $\begin{array}{c}\text { M25 structure } \\
\text { (without fibers) }\end{array}$ & 5 & 0.015926 & 397.26 \\
\cline { 2 - 4 } & 6 & 0.019707 & 497.74 \\
\cline { 2 - 4 } & 8 & 0.025406 & 649.19 \\
\hline \multirow{2}{*}{$\begin{array}{c}\text { M25+0.5\% steel } \\
\text { fibers }\end{array}$} & 5 & 0.014182 & 347.49 \\
\cline { 2 - 4 } & 6 & 0.017549 & 435.38 \\
\cline { 2 - 4 } & 8 & 0.022624 & 567.85 \\
\hline \multirow{2}{*}{$\begin{array}{c}\text { M25 + 1\% steel } \\
\text { fibers }\end{array}$} & 5 & 0.01363 & 333.96 \\
\cline { 2 - 4 } & 6 & 0.016866 & 418.43 \\
\cline { 2 - 4 } & 8 & 0.021744 & 545.75 \\
\hline \multirow{2}{*}{$\begin{array}{c}\text { M25 + 1.5\% steel } \\
\text { fibers }\end{array}$} & 5 & 0.01320 & 321.09 \\
\cline { 2 - 4 } & 6 & 0.016362 & 402.73 \\
\cline { 2 - 4 } & 8 & 0.021093 & 525.27 \\
\hline \multirow{2}{*}{$\begin{array}{c}\text { M25 + 2\% steel } \\
\text { fibers }\end{array}$} & 5 & 0.0130 & 315.6 \\
\cline { 2 - 4 } & 6 & 0.016181 & 396.64 \\
\cline { 2 - 4 } & 8 & 0.02086 & 517.33 \\
\hline
\end{tabular}

It is observed that the strains are very high at ground level and at the base and also at the beam column joints in almost all the storeys. The failure mechanisms of the structural elements such as the columns to the beams and slabs which were connected to it is as shown in the Figure 18. The variation of HS's for blast load analysis of $3 \mathrm{~m}$ standoff distance as illustrated in Figure 19.

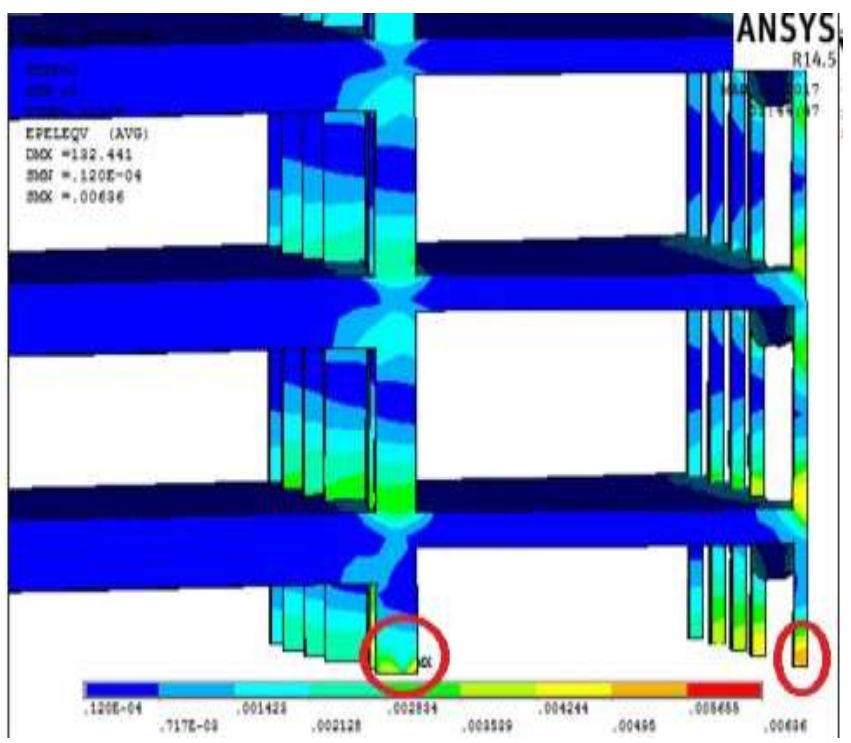

Figure 18. Blast load analysis performed for M25concrete structure 


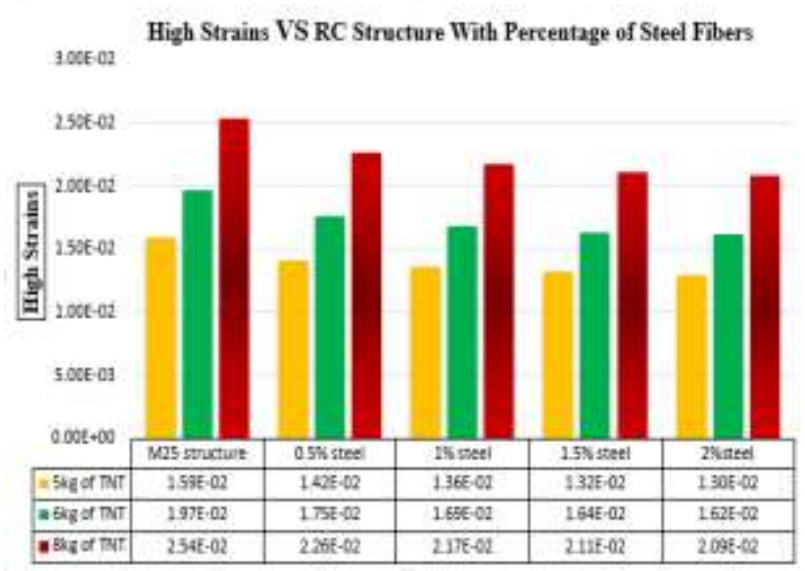

Figure 19. Variation of HS's for 3m standoff distance.

The blast load analysis was performed by using ANSYS version 14.5 and the analytical results as illustrated in Figure. 20 and the variation in LD's with $3 \mathrm{~m}$ standoff distance and $5 \mathrm{~kg}, 6 \mathrm{~kg}$ and $8 \mathrm{~kg}$ of TNT with respect to conventional structure and the structures with steel fibers as illustrated in Figure. 21.

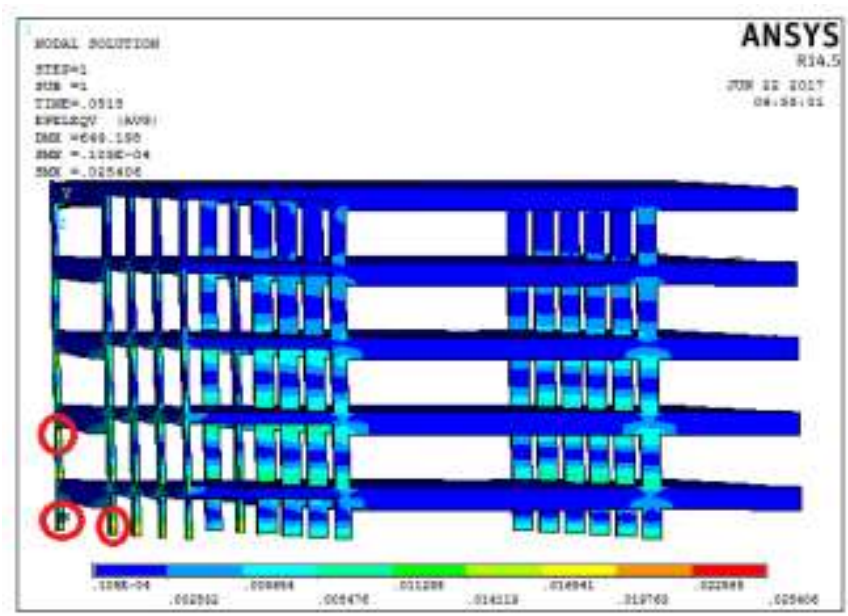

Figure 20. Blast load analysis of $3 \mathrm{~m}$ standoff and $5 \mathrm{~kg}$ of TNT

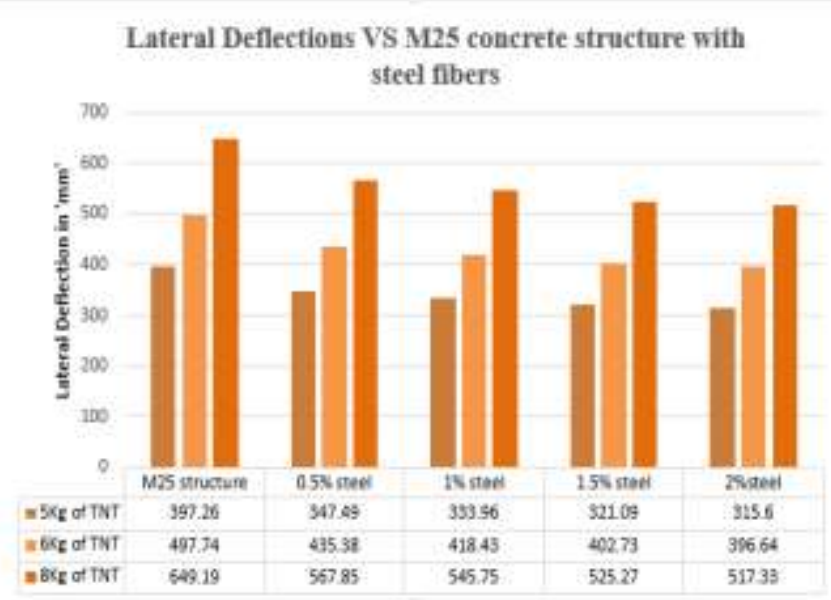

Figure 21. Variation of LD's at $3 \mathrm{~m}$ standoff and $5 \mathrm{~kg}, 6 \mathrm{~kg}$ and $8 \mathrm{~kg}$ of TNT

\section{B. $6 \boldsymbol{m}$ standoff distance \& 5, 6 and $8 \mathrm{~kg}$ of TNT}

The HSs at $6 \mathrm{~m}$ standoff distance and with $5 \mathrm{~kg}$ of TNT for structure with M25 grade of concrete and structure with $0.5 \%, 1 \%, 1.5 \%$ and $2 \%$ steel fibres were observed as $0.00465,0.00394,0.00379$, 0.00350 and 0.00347 respectively. The HSs decreased by $15.34 \%, 18.56 \%, 24.8 \%$ and $25.44 \%$ respectively compared to structure without fibres. At $6 \mathrm{~m}$ and $6 \mathrm{~kg}$ of TNT, the HSs observed were $0.00502,0.00426,0.00409,0.00388$ and 0.00374 . HS decreased by $15.34 \%, 18.56 \%, 22.71 \%$ and $25.5 \%$ respectively when compared to the structure without fibres. At $6 \mathrm{~m}$ and $8 \mathrm{~kg}$ of TNT the HSs observed were $0.00636,0.00539,0.00518,0.00492$ and 0.00438 . The HSs decreased by $15.25 \%$, $18.55 \%, 22.64 \%$ and $31.13 \%$ respectively as compared to the structure without fibres. The variation of HS's for blast load analysis of $6 \mathrm{~m}$ standoff distance is as illustrated in Figure 22.

At $5 \mathrm{~kg}$ of TNT charge weight and at $6 \mathrm{~m}$ standoff distance the conventional structure with M25 grade of concrete and structures with $0.5 \%$, $1 \%, 1.5 \%$ and $2 \%$ steel fibers, the LDs observed were $83.51 \mathrm{~mm}, 73.05 \mathrm{~mm}, 70.21 \mathrm{~mm}, 67.57 \mathrm{~mm}$ and $66.42 \mathrm{~mm}$. The decrease in LDs observed were $12.53 \%, 15.94 \%, 19.09 \%$ and $20.31 \%$ respectively. At $6 \mathrm{~kg}$ of TNT charge weight and at $6 \mathrm{~m}$ standoff distance the conventional structure with M25 grade of concrete and structures with $0.5 \%, 1 \%, 1.5 \%$ and $2 \%$ steel fibers, the LDs observed were $93.96 \mathrm{~mm}$, $82.19 \mathrm{~mm}, 78.99 \mathrm{~mm}, 76.03 \mathrm{~mm}$ and $74.75 \mathrm{~mm}$ respectively and corresponding decrease in LDs observed were $12.53 \%, 15.94 \%, 19.09 \%$ and $20.31 \%$ respectively. At $8 \mathrm{~kg}$ of TNT charge weight and at $6 \mathrm{~m}$ standoff distance, the structure with M25 grade of concrete when compared with structures with $0.5 \%, 1 \%, 1.5 \%$ and $2 \%$ steel fibers, the LD's were observed was $132.44 \mathrm{~mm}, 115.85 \mathrm{~mm}$, $114.54 \mathrm{~mm}, 107.17 \mathrm{~mm}$ and $94.27 \mathrm{~mm}$ and the corresponding decrease in LD's were observed as $12.53 \%, 15.94 \%, 19.09 \%$ and $20.31 \%$ respectively. The variation in LD's with $6 \mathrm{~m}$ standoff distances and $5 \mathrm{~kg}, 6 \mathrm{~kg}$ and $8 \mathrm{~kg}$ TNT with respect to conventional structure and the structure with steel fibers is as illustrated in Figure 23. 
Table VI. HIGH STRAINS AND LATERAL DEFLECTIONS FOR 6M STANDOFF, STRUCTURE WITH \&WITHOUT FIBERS

\begin{tabular}{|c|c|c|c|}
\hline $\begin{array}{c}\text { Type of } \\
\text { structure }\end{array}$ & $\begin{array}{c}\text { Charge } \\
\text { weight } \\
\text { (kg) }\end{array}$ & $\begin{array}{c}\text { High } \\
\text { Strains }\end{array}$ & $\begin{array}{c}\text { Lateral } \\
\text { Deflections } \\
\text { (mm) }\end{array}$ \\
\hline $\begin{array}{c}\text { M25 structure } \\
\text { (without fibers) }\end{array}$ & 5 & 0.00465 & 83.51 \\
\cline { 2 - 4 } & 6 & 0.00502 & 93.96 \\
\cline { 2 - 4 } & 8 & 0.00636 & 132.44 \\
\hline \multirow{2}{*}{$\begin{array}{c}\text { M25+0.5\% steel } \\
\text { fibers }\end{array}$} & 5 & 0.00394 & 73.05 \\
\cline { 2 - 4 } & 6 & 0.00426 & 82.19 \\
\cline { 2 - 4 } & 8 & 0.00539 & 115.85 \\
\hline $\begin{array}{c}\text { M25 + 1\% steel } \\
\text { fibers }\end{array}$ & 5 & 0.00379 & 70.21 \\
\cline { 2 - 4 } & 6 & 0.00409 & 78.99 \\
\hline \multirow{2}{*}{$\begin{array}{c}\text { M25 + 1.5\% steel } \\
\text { fibers }\end{array}$} & 5 & 0.00518 & 114.34 \\
\cline { 2 - 4 } & 6 & 0.00388 & 76.03 \\
\cline { 2 - 4 } & 8 & 0.00492 & 107.17 \\
\hline \multirow{2}{*}{$\begin{array}{c}\text { M25 + 2\% steel } \\
\text { fibers }\end{array}$} & 5 & 0.00347 & 66.42 \\
\cline { 2 - 4 } & 6 & 0.00374 & 74.75 \\
\cline { 2 - 4 } & 8 & 0.00438 & 94.27 \\
\hline
\end{tabular}

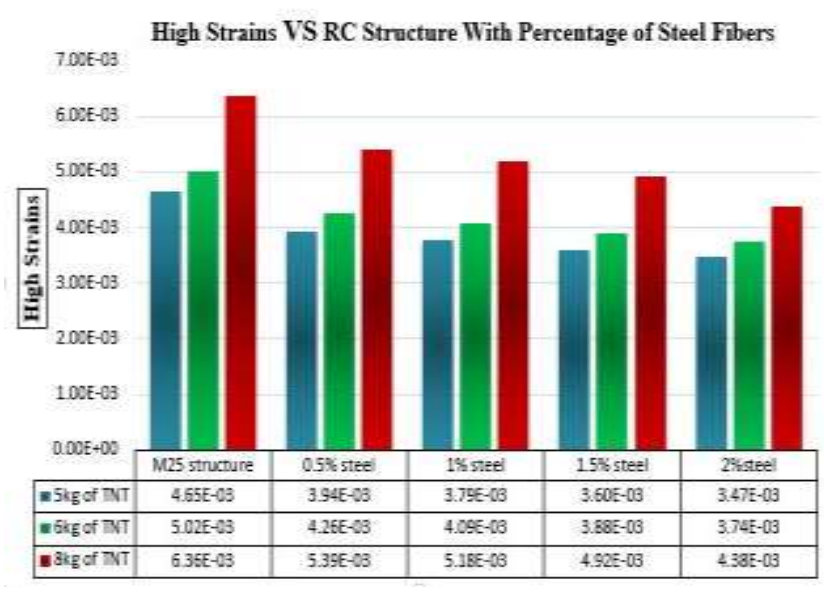

Figure 22. Variation of HS's for $6 \mathrm{~m}$ standoff distance

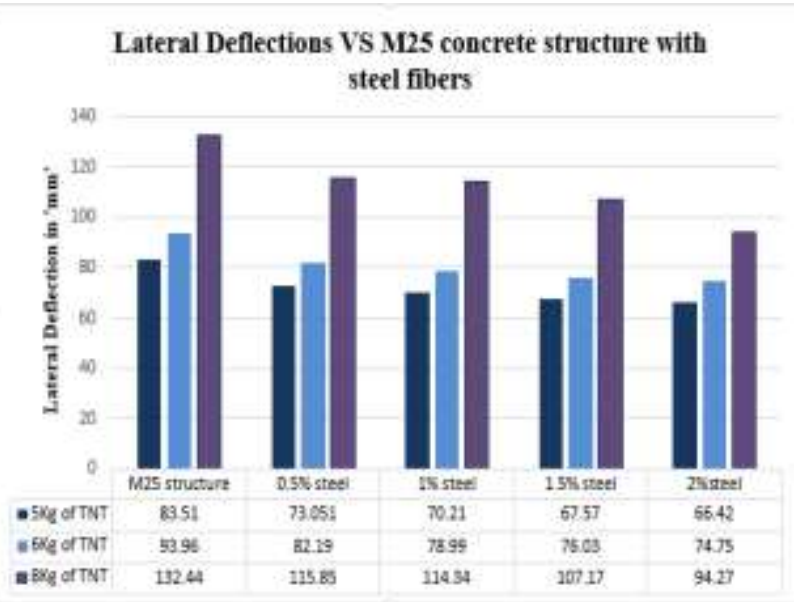

Figure 23. Variation of LD's at $6 \mathrm{~m}$ standoff and $5 \mathrm{~kg}, 6 \mathrm{~kg}$ and $8 \mathrm{~kg}$ of TNT

\section{9m standoff distance \& 5,6 and $8 \mathrm{~kg}$ of TNT}

The HSs at $9 \mathrm{~m}$ standoff distance and with $5 \mathrm{~kg}$ of TNT for structure with M25 grade of concrete when compared with structure consisting of $0.5 \%, 1 \%, 1.5 \%$ and $2 \%$ steel fibres were observed as $0.00365,0.00308,0.00296,0.00281$ and 0.00275 . The HSs decreased by $15.88 \%$, $18.96 \%, 23.04 \%, 24.71 \%$ respectively as compared to structure without steel fibres. At $9 \mathrm{~m}$ and $6 \mathrm{~kg}$ of TNT the HSs observed were 0.00502, 0.00426, $0.00409,0.00388,0.00374$ and HSs decreased by $15.73 \%, 18.56 \%, 22.71 \%$ and $25.5 \%$ respectively. At $9 \mathrm{~m}$ and $8 \mathrm{~kg}$ of TNT the HS's results observed were $0.00431,0.00365,0.00351,0.00333$ and 0.00326 respectively. HSs decreased by $15.23 \%$, $18.52 \%, 22.81 \%$, and $24.43 \%$ respectively when compared to structure without fibres. The variation of HSs for blast load analysis of $9 \mathrm{~m}$ standoff distance is as illustrated in Figure 24.

At $5 \mathrm{~kg}$ of TNT charge weight and at $9 \mathrm{~m}$ standoff distance the conventional structure with M25 grade of concrete and structures with $0.5 \%$, $1 \%, 1.5 \%$ and $2 \%$ steel fibers, the LD's were observed as $54.90 \mathrm{~mm}, 47.53 \mathrm{~mm}, 45.68 \mathrm{~mm}$, $43.96 \mathrm{~mm}$ and $43.30 \mathrm{~mm}$ respectively and decrease in LD's resulted as $13.42 \%, 16.79 \%, 19.93 \%$ and $21.13 \%$ respectively. At $6 \mathrm{~kg}$ of TNT charge weight and at $9 \mathrm{~m}$ standoff distance the conventional structure with M25 grade of concrete and structures with $0.5 \%, 1 \%, 1.5 \%$ and $2 \%$ steel fibers, the LD's were observed as $64.47 \mathrm{~mm}, 56.02 \mathrm{~mm}, 53.84 \mathrm{~mm}$, $51.82 \mathrm{~mm}$ and $51.03 \mathrm{~mm}$ and decrease in LDs observed were $13.11 \%, 16.49 \%, 19.03 \%$ and $20.44 \%$ respectively. At $8 \mathrm{~kg}$ of TNT charge weight and at $9 \mathrm{~m}$ standoff distance, the conventional structure with M25 grade of concrete and structures with $0.5 \%, 1 \%, 1.5 \%$ and $2 \%$ steel fibers, the LDs observed were $73.78 \mathrm{~mm}, 64.53 \mathrm{~mm}, 62.02 \mathrm{~mm}$, $59.69 \mathrm{~mm}$ and $58.79 \mathrm{~mm}$ respectively. The decrease in LDs observed were $12.54 \%, 15.94 \%, 19.09 \%$ and $20.31 \%$ respectively. The variation in LD's with $9 \mathrm{~m}$ standoff distance and $5 \mathrm{~kg}, 6 \mathrm{~kg}$ and $8 \mathrm{~kg}$ TNT with respect to conventional structure and the structure with steel fibers is as illustrated in Figure 25. 
TABLE VII. HIGH STRAINS AND LATERAL DEFLECTIONS FOR 9M STANDOFF, STRUCTURE WITH \&WITHOUT FIBERS

\begin{tabular}{|c|c|c|c|}
\hline $\begin{array}{c}\text { Type of } \\
\text { structure }\end{array}$ & $\begin{array}{c}\text { Charge } \\
\text { weight } \\
(\mathbf{k g})\end{array}$ & $\begin{array}{c}\text { High } \\
\text { Strains }\end{array}$ & $\begin{array}{c}\text { Lateral } \\
\text { Deflections }(\mathbf{m m})\end{array}$ \\
\hline $\begin{array}{c}\text { M25 structure } \\
\text { (without } \\
\text { fibers) }\end{array}$ & 5 & 0.00365 & 54.90 \\
\cline { 2 - 4 } & 6 & 0.00398 & 64.47 \\
\hline \multirow{2}{*}{$\begin{array}{c}\text { M25+0.5\% } \\
\text { steel fibers }\end{array}$} & 5 & 0.00431 & 73.78 \\
\cline { 2 - 4 } & 6 & 0.00308 & 47.53 \\
\cline { 2 - 4 } & 8 & 0.00336 & 56.02 \\
\hline \multirow{2}{*}{$\begin{array}{c}\text { M25+1\% } \\
\text { steel fibers }\end{array}$} & 5 & 0.00365 & 64.53 \\
\cline { 2 - 4 } & 6 & 0.00323 & 45.68 \\
\hline \multirow{2}{*}{$\begin{array}{c}\text { M25+1.5\% } \\
\text { steel fibers }\end{array}$} & 5 & 0.00351 & 53.84 \\
\cline { 2 - 4 } & 6 & 0.00307 & 62.02 \\
\hline \multirow{2}{*}{$\begin{array}{c}\text { M25 +2\% } \\
\text { steel fibers }\end{array}$} & 5 & 0.00333 & 53.96 \\
\cline { 2 - 4 } & 6 & 0.00275 & 43.82 \\
\cline { 2 - 4 } & 8 & 0.00300 & 51.03 \\
\hline
\end{tabular}

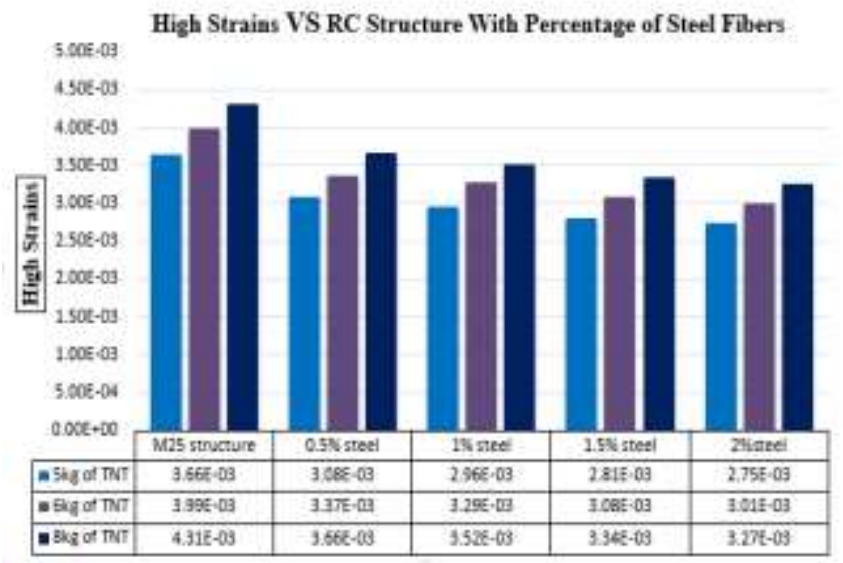

Figure 24. Variation of HS's for 9m standoff distance and $5 \mathrm{~kg}$, $6 \mathrm{~kg}$ and $8 \mathrm{~kg}$ of TNT

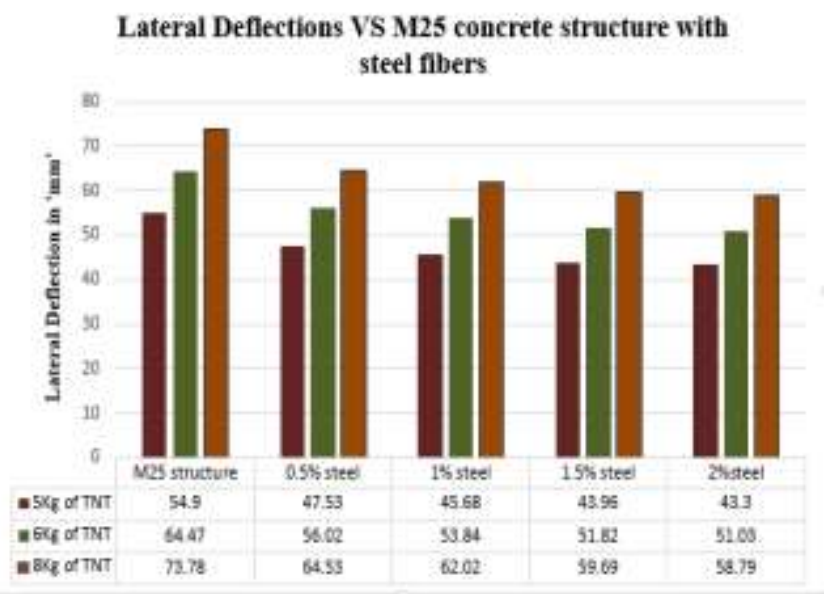

Figure 25. Variation of LD's at 9m standoff and $5 \mathrm{~kg}, 6 \mathrm{~kg}$ and $8 \mathrm{~kg}$ of TNT

\section{Conclusions}

For the public buildings such as hospitals, administrative buildings, residential buildings and commercial buildings, the design considerations for extreme events are very important.

The study revealed that, the intensity of high strains and deformations is larger near the beam column joint than in the rest of the column. At different floor levels the intensity of impact decreases as the distance from the surface of blast increases. As the standoff distances increases the deformation as well as the high strains values decreases.

Maximum strain occurs at base of the column especially at the rear face of the building as shown in the results. To control these intense but short duration loads, the material properties to be improved either by higher grades of concrete or by including fibres into concrete.

From the results obtained, it can be concluded that to improve the material properties, steel fibres can be included to resist the blast loads. The values of high strains and lateral deflections decreased as compared to conventional structure without steel fibres.

The lateral deflections for conventional M25 concrete structure are very high when compared to the structure with steel fibers. As the standoff distances decreases the intensity of blast loads increases leading to variation in response of the structure. Increase in Young's modulus leads to increase in the moment of resistance of structure and correspondingly increase in the strain capacity of the structure. From the results obtained for lateral deflections, when compared with the M25 concrete and the structures with steel fibres, it is evident that as the charge weight increases the deflections also increases.

The results obtained for $1 \%$ and $1.5 \%$ steel fibres with an aspect ratio of 50, suggest that optimum percetnatge of fibres lies between $1 \%$ 1.5 that respond well to the blast loads.

At $3 \mathrm{~m}$ and less standoff distance the strain levels are very high and there may be severe cracking, slipping of bars and spalling of concrete which would occur. 


\section{Scope for the future work}

1. Blast load analysis for the complete structure with the structural elements such doors, windows and walls to be considered to determine the passive response.

2. Transient analysis to be performed to understand the response of the buildings and also the high strain rates variation with respect to time.

3. Isolation of the base for the structures at the level of foundation may be done to understand the dynamic response of the structure and its elements due to blast loads.

\section{References}

[1] JunLi, Chengqing Wu, and HongHao, "Blast resistance of concrete slab reinforced with high performance fibre material," Journal of Structural Integrity and Maintenance, vol. 1, no. 2, pp. 51-59, 02 June 2016

[2] Xiaoshan Lin and Y. X. Zhang, "Nonlinear Finite Element Analysis of FRPStrengthened Reinforced Concrete Panels Under Blast Loads ," International JournalofComputationalMethods.,vol.13, no.4,pp.1641002: 1-17,08January2016.

[3] SalehH. Alsayed and H.M.Elsanadedy, "Blast response of GFRP-strengthened infill masonry walls," Construction and Building Materials, pp. 438-451, 11 April 2016.

[4] Dasari Sudheer Kumar, Pallavi Rai and Rajneesh Kumar, "Behaviour of Reinforced Concrete Building Frame Subjected to Different Types of Blast Loading," Indian Journal of Science and Technology, vol. 9, no. 23, June 2016.

[5] Hong Hao, Gang Chen and Yifei Hao, "Experimental tests of steel fibre reinforced concrete beams under drop-weight impacts," Key Engineering Materials, vol. 626 pp. 311316, 07 December 2015.

[6] Jun Li and Hong Hao, "Numerical study of concrete spall damage to blast loads", International Journal of Impact Engineering, vol. 68, pp. 41-55, 8 February 2014.

[7] Juechun $\mathrm{Xu}$, "Behaviour of Ultra High Performance Concrete Columns Subjected to Blast Loadings Construction and Building Materials", 2015.

[8] Damasceno Iana Ingrid Rocha, Maur'ıcio de Pina Ferreira and D`enio Ramam Carvalho de Oliveira, "RC beams with steel fibres under impact loads," Acta Scientiarum. Technology, vol. 36, no. 1 pp. 23-31, March 2014

[9] Mohammed Alias Yusof and Norazman, "Normal Strength Steel Fiber Reinforced Concrete Subjected to Explosive Loading", International Journal of Sustainable Construction Engineering and Technology, vol. 1, no. 2, December 2010.

[10] T. Ngo, P. Mendis, A. Gupta and J. Ramsay, "Blast Loading and Blast Effects on Structures - An Overview," EJSE Special Issue: Loading on Structures, 2007.

[11] Z.XianLia, "A new method for progressive collapse analysis,"ElsevierLtd, no.29, March 2010.

[12] Damasceno Iana Ingrid Rocha, Maur'́cio de Pina Ferreira and D^enio Ramam Carvalho de Oliveira, "Design and Analysis of Blast Load on Structures," International Research Journal of Engineering and Technology (IRJET), vol.02, no.1pp. 745-747, October 2015.
[13] Y.S. Tai and T.L. Chu, "Dynamic response of a reinforced concrete slab subjected to air blast load," Theoretical and Applied Fracture Mechanics, vol. 56, pp. 140147, 15 November 2011.

[14] Carter. C, "Hand Book for Blast Resistant Design of Buildings", pp. 386.Canada: John Wiley and Sons, Inc.

[15] BIS 4991:1968, Indian Standard on Blast Load Resistant Design of Structures for the Blasts above Ground, Bureau of Indian Standards, New Delhi.

[16] A.K. Pandey et al., "Non-linear response of reinforced concrete containment structure", Journal of Nuclear Engineering and design, vol. 236, pp. pp.993-1002., April 2006.

[17] J.M. Dewey, "The Properties of Blast Waves Obtained from an analysis of the particle," A.314, pp. 275-299., Scotland, 1971.

[18] J.I. Siddiqui, "Impulsive loading on structures," Proceedings of Institution of Civil Engineers (Structure and Buildings), pp. 231-241, 2012.

\section{Acknowledgment}

The authors wish to place on record the encouragement and support extended by the Faculty of Engineering, Christ University, Bengaluru, India for the research undertaken.

About Author (s):

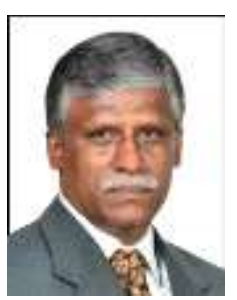

Raghunandan Kumar R, is currently working as Associate Professor at Department of Civil Engineering, Faculty of Engineering, Christ University, Bengaluru, India

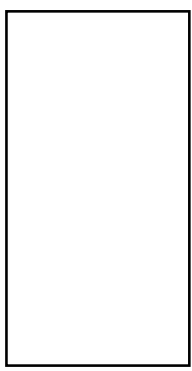

Prof. G. R. Reddy, Ph. D (TMU,Japan)

Outstanding Scientist, Head, Structural and Seismic Engineering Section,

Senior Professor, Homi Bhabha National Institute \& Teacher for Ph.Ds, University of Mumbai and Christ University,

Reactor Safety Division,

Bhabha Atomic Research Centre,

Trombay, Mumbai, India.

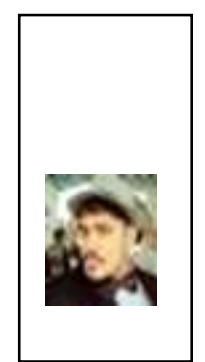

Sunny Dev K, Georgy, Job abd Alinna Benny, Students of Master of Technology, Department of Civil Engineering, Faculty of Engineering, Christ University, Bengaluru, India 